\title{
PEMETAAN POTENSI ANAK DENGAN KESULITAN BELAJAR SPESIFIK DISLEKSIA
}

\section{Studi Kasus di Homeschooling Lentera Bangsa Desa Margahayu Selatan, Kec. Margahayu, Kabupaten Bandung}

Tiffany Estherlita1, Ansori Al-B ${ }^{2}$, Novi Widiastuti ${ }^{3}$

1,2,3 IKIP Siliwangi

1iffanyestherlita@gmail.com

\begin{abstract}
Abstrak
Setiap manusia diciptakan dengan begitu unik melalui setiap potensi dan kekurangannya masing-masing. Maka dari itu proses pembelajaran yang baik adalah proses pembelajaran yang sesuai dengan kebutuhan setiap individu dengan memperhatikan apa yang menjadi kelebihan dan kekurangannya, sehingga setiap individu dapat memetakan dan memaksimalkan potensi yang ia miliki. Namun, pada proses pembelajaran ditemukan adanya anak-anak yang mengalami kesulitan belajar spesifik dyslexia yang tidak terdeteksi dan tertangani sehingga menimbulkan label yang salah terhadap anak-anak yang mengalami kesulitan belajar spesifik ini. Maka dari itu, penelitian ini bertujuan untuk membantu guru dan orangtua untuk dapat memetakan potensi anak dengan kesulitan belajar spesifik dengan cara mengidentifikasi kebutuhan dan gaya belajar anak disleksia di Homeschooling Lentera Bangsa. Metode yang digunakan dalam penelitian ini yaitu metode quasi experimental. Teknik pengumpulan data dilakukan dengan menggunakan purposive sampling. Penelitian ini menghasilkan konsep pemetaan potensi anak dengan kesulitan belajar spesifik (dyslexia) sehingga guru dan orangtua dapat memfasilitasi anak untuk memaksimalkan potensinya.
\end{abstract}

Kata kunci : pemetaan potensi, kesulitan belajar spesifik, dyslexia

\section{PENDAHULUAN}

Aspek kognitif merupakan salah satu aspek yang penting bagi perkembangan dan pertumbuhan seorang anak. Kemampuan kognitif anak dapat di kembangkan melalui serangkaian kegiatan belajar. Namun, seringkali dalam beberapa kasus ditemukan adanya anak yang mengalami kesulitan belajar. Hal ini sering terdeteksi ketika anak sudah duduk dibangku sekolah yang menyebabkan anak sulit memahami materi pembelajaran yang diberikan oleh guru. Beberapa anak juga diketahui bukan hanya mengalami kesulitan belajar biasa, tetapi mengalami kesulitan belajar spesifik. Menurut Solek (2015) kesulitan belajar spesifik adalah kesulitan anak dalam hal baca (dyslexia), tulis (dysgraphia) dan hitung (dyscalculia) yang ditemukan pada anak dengan tingkat itelegensia rata-rata (normal), bahkan berada pada posisi diatas rata-rata.

Sebanyak 90\% siswa dengan kesulitan belajar juga mengalami kesulitan membaca (Lyon, 1996). Berdasarkan data yang dilansir Kompas dalam jurnal yang ditulis Widayanti (2012), 
Indonesia termasuk negara yang memiliki masalah kesulitan belajar membaca. Indeks kemampuan membaca siswa SD di Indonesia jauh berada di bawah indeks Singapura.

Menurut hasil data yang dimiliki Homeschooling Lentera Bangsa yang berlokasi di Taman Kopo Indah 1 Blok C No.78 RT003/RW015 Desa Margahayu Selatan, Kecamatan Margahayu, Kabupaten Bandung sebanyak 3 (tiga) anak yang berada pada jenjang 3 SD Tahun Ajaran 2017-2018 mendapatkan diagnosa mengalami kesulitan belajar spesifik disleksia oleh dokter perkembangan anak.

Pemahaman yang kurang terhadap kesulitan belajar spesifik disleksia mengakibatkan ketidakmampuan guru dan orangtua untuk memberikan metode pembelajaran yang tepat sehingga anak dapat mengalami tekanan yang diakibatkan oleh metode pembelajaran yang salah dan tuntutan dari guru maupun orangtua yang berdampak negatif bagi perkembangan anak tersebut. Anak dengan kesulitan belajar spesifik disleksia yang tidak terdeteksi dan terfasilitasi dalam proses pembelajaran yang tepat cenderung mendapat label yang salah dari guru, orangtua, teman dan lingkungan sekitarnya.

Proses pembelajaran yang baik tentunya harus membantu setiap guru dan orangtua untuk dapat memetakan potensi anak, sehingga guru dan orangtua mampu megarahkan anak tersebut untuk menyadari potensinya dan memunculkan motivasi anak untuk memaksimalkan potensi dalam dirinya. Potensi yang ada dalam diri seseorang jika dimaksimalkan mampu menjadi modal yang baik untuk hidup dimasa kini dimasa yang akan datang.

Menurut UUD 1945 Pasal 31 bahwa "setiap warga negara berhak mendapatkan pendidikan", UU Nomor 20 Tahun 2003 Pasal 3 yang berbunyi "Pendidikan nasional berfungsi mengembangkan kemampuan dan membentuk watak serta peradaban bangsa yang bermartabat dalam rangka mencerdaskan kehidupan bangsa, bertujuan untuk berkembangnya potensi peserta didik agar menjadi manusia yang beriman dan bertakwa kepada Tuhan Yang Maha Esa, berakhlak mulia, sehat, berilmu, cakap, kreatif, mandiri, dan menjadi warga negara yang demokratis serta bertanggung jawab." dan Pasal 12 Poin $1 \mathrm{~b}$ menyatakan "Setiap peserta didik pada setiap satuan pendidikan berhak mendapatkan pelayanan pendidikan sesuai dengan bakat, minat, dan kemampuannya;".

Hal ini senada dengan seorang pakar psikologi humanistis, Maslow (1954) yang menjelaskan bahwa kegiatan pembelajaran hendaknya didasarkan atas kebutuhan peserta didik. Dan Rogers dalam Sudjana (2013:91) mengemukakan bahwa kegiatan pembelajaran itu berpusat pada peserta didik.

Identifikasi masalah dalam penelitian ini adalah : 1) Kurang tepatnya metode pembelajaran yang digunakan oleh guru bagi anak dengan kesulitan belajar disleksia. Hal ini dapat dilihat dari tingkat motivasi belajar sisw yang rendah dan tingkat stress belajar siswa yang tinggi, 2) Kesulitan guru dalam hal mengendalikan kelas yang terdapat anak dengan kesulitan belajar disleksia. Hal ini dapat dilihat dari kurang kondusifnya keadaan kelas tersebut dalam proses pembelajaran, dan 3) Tidak terpetakannya potensi anak dengan kesulitan belajar disleksia. Hal ini dapat dilihat dari kurangnya pemahaman orangtua dan guru tentang potensi anak tersebut. 
Berdasarkan hasil identifikasi kebutuhan tersebut maka tujuan penelitian ini adalah : 1) Mengetahui cara mengidentifikasi kebutuhan peserta didik sebagai data awal untuk tahap penyusunan instrumen dalam proses pemetaan potensi, 2) Mengetahui keadaan anak dengan kesulitan belajar spesifik disleksia pada peserta didik level 3 di Homeschooling Lentera Bangsa, dan 3) Menemukan metode pembelajaran yang tepat bagi anak dengan kesulitan belajar spesifik disleksia di Homeschooling Lentera Bangsa.

\section{LANDASAN TEORI}

Rogers dalam Sudjana (2013:91) menengemukakan bahwa kegiatan pembelajaran itu berpusat pada peserta didik (learner centered). Hal ini menegaskan bahwa perlu adanya identifikasi kebutuhan peserta didik yang harus dilakukan sebelumnya untuk merancang sebuah kegiatan pembelajaran yang sesuai dengan kebutuhan dan kepentingan peserta didik dalam mengikuti proses pembelajaran itu sendiri sehingga tujuan pendidikan itu tercapai.

Hal ini didukung oleh teori motivasi yang dikembangkan oleh Maslow (1954), ia berpendapat bahwa manusia memiliki lima tingkat kebutuhan, yaitu : (1) kebutuhan fisiologikal; (2) kebutuhan rasa aman; (3) kebutuhan akan kasih sayang; (4) kebutuhan akan harga diri; dan (5) aktualisasi diri. Teori ini menjelaskan bahwa ada kebutuhankebutuhan seseorang yang harus dipenuhi, dalam arti tersedianya suatu kesempatan bagi seseorang untuk merubah sebuah kesempatan dalam mengembangkan potensi dalam dirinya menjadi sebuah kemampuan yang nyata sehingga berguna bagi kehidupannya saat ini dan dimasa yang akan datang.

Menurut Suryani (2010) disleksia atau kesulitan membaca adalah kesulitan untuk memaknai simbol, huruf, dan angka melalui presepsi visual dan auditoris. Hal ini berdampak pada kemampuan membaca pemahaan.

Dalam hal ini diperlukan sebuah rancangan kegiatan pembelajaran yang sesuai dengan kebutuhan setiap orang dan perlu dipahami bahwa setiap orang adalah unik dan berbeda, terlebih dalam hal ini adalah anak dengan kesulitan belajar spesifik disleksia yang memerlukan treatment khusus agar materi pembelajaran yang disampaikan dapat diterima dengan baik dengan metode pembelajaran yang khusus pula sehingga dalam proses pemebelajaran tersebut ia mampu mengenali apa yang menjadi potensi dalam dirinya disertai dengan peran guru dan orangtua yang mampu mengarahkan dan memotivasi anak tersebut untuk dapat memaksimalkan potensinya.

Menurut Royani dalam Liputan6.com (2014) pemetaan potensi merupakan cara asesmen atau menilai dan menggali bakat (karateristik produktif) dan potensi kekuatan kita dengan tampilan hasil yang lengkap, mudah dipahami dan menarik. Cara ini bisa mengidentifikasi potensi kekuatan individu yang mencakup pengukuran dan pernyataan kekuatan diri (Personal Strengths Statement).

Seseorang harus mengetahui apa yang menjadi kelebihan, kelemahan, minat dan bakat atau potensi dirinya sendiri. Pemetaan potensi peserta didik merupakan hal yang penting untuk dilakukan dalam sebuah proses pembelajaran. Namun, dalam pengimplementasian proses pembelajaran klasikal kurang tepat untuk dapat menggali atau memetakan potensi peserta didik. Maka dari itu harus adanya sebuah metode pembelajaran yang disesuaikan 
dengan hasil identifikasi kebutuhan peserta didik dalam sebuah kelompok belajar dalam hal ini anak dengan kesulitan belajar disleksia.

\section{METODE PENELITIAN}

Pendekatan yang digunakan dalam penelitian adalah pendekatan kualitatif. Metode yang digunakan pada penelitian ini adalah quasi experimental. Metode ini digunakan karena penelitian ini bertujuan untuk membandingkan metode pembelajaran terdahulu (klasikal) dengan metode pembelajaran baru bagi anak dengan kesulitan belajar spesifik disleksia.

Populasi yang digunakan dalam penelitian ini yaitu peserta didik level 3 di Homeschooling Lentera Bangsa periode 2018-2019. Adapun teknik penentuan sampel dalam penelitian ini adalah dengan menggunakan teknik purposive sampling. Teknik ini sangat cocok untuk digunakan dalam penelitian ini karena jumlah sampel yang diambil hanya pada peserta didik level 3 di Homeschooling Lentera Bangsa periode 2017-2018. Sampel penelitian ini yaitu level 3 (usia 8-10 tahun) dengan diagnosa dyslexia berjumlah 3 orang.

Teknik pengumpulan data diambil melalui wawancara, analisis dokumen, diskusi, observasi, dokumentasi (foto dan rekaman video). Teknik analisis yang digunakan dalam penelitian ini adalah triangulasi metode untuk menemukan kebenaran informasi dari berbagai sumber data dan informan yang meliputi guru, orangtua dan terapis/psikolog.

\section{HASIL DAN PEMBAHASAN}

\section{Hasil}

Pertama, identifikasi kebutuhan sesuai dengan hasil diagnosa dokter tumbuh kembang anak dan psikolog bahwa CEG, SC, dan SD di diagnosa sebagai anak dengan kesulitan belajar disleksia merupakan data awal untuk tahap penyusunan instrumen dalam proses pemetaan potensi. Kemudian hal selanjutnya yang dapat disusun adalah strategi, akomodasi dan pendekatan cara belajar yang sesuai.

Kedua, berdasarkan hasil identifikasi kebutuhan maka strategi yang tepat untuk CEG, SC, dan SD menggunakan kode warna, flash card, mind map, dan free time. Dan dapat menggunakan pendekatan cara belajar : 1) visual melalui bantuan media konkrit, komputer dan alat warna, 2) auditori menggunakan alat musik dan lagu, dan 3) kinestetik halus dan kasar.

Ketiga, berdasarkan hasil evaluasi proses belajar yang banyak menggunakan media gambar menghasilkan peningkatan kemampuan CEG dalam memahami instruksi yang diberikan oleh guru karena mampu menjawab setiap soal yang ia pahami dengan gambar dan kata sederhana (belum berupa kalimat).

Proses belajar yang banyak memfasilitasi SC untuk dapat mengerjakan meteri pembelajaran dengan kreasi dan bangun ruang dan gerak menghasilkan peningkatan kemampuan SC dalam memahami instruksi yang diberikan oleh guru karena SC mampu menjawab setiap materi yang ia pahami secara lisan melalui kegiatan.

Hasil proses belajar yang banyak memfasilitasi SD untuk dapat mengerjakan meteri pembelajaran dengan kreasi dan teknologi menghasilkan peningkatan kemampuan SD 
dalam memahami instruksi yang diberikan oleh guru karena SD mampu menjawab setiap materi yang ia pahami secara lisan melalui kegiatan belajar melalui games edukatif.

\section{Pembahasan}

Pertama, penyusunan instrumen pemetaan potensi yang berisi strategi, akomodasi dan pendekatan cara belajar yang tepat bagi anak dengan kesulitan belajar spesifik disleksia dapat disusun berdasarkan hasil report dari dokter tumbuh kembang anak dan psikolog. Hal ini dilakukan untuk membantu guru dalam memahami keadaan anak tersebut sehingga guru dapat membuat sebuah metode pembelajaran yang sesuai dan efektif. Dengan metode pembelajaran yang sesuai dengan kebutuhan dan berpusat pada peserta didik dapat meningkatkan motivasi belajar dan meminimalisir tingkat stress belajar pada peserta didik. Hal ini sesuai pula dengan teori yang dikatakan Rogers dalam Sudjana (2013:91) dan Maslow (1954).

Kedua, seperti yang dijelaskan Suryani (2010) dalam hal penyusunan strategi, akomodasi dan pendekatan cara belajar yang tepat bagi CEG, SC, SD dengan melihat tingkat disleksia yang berbeda ssatu sama lain maka setiap instrumennyapun harus dibedakan dengan kebutuhan masing-masing. Seperti dalam pembelajaran, CEG digunakan pendekatan visual gambar dan auditori musik. Maka CEG lebih banyak diberikan soal-soal dalam bentuk gambar dan lisan, penggunaan flash card, dan menentukan ukuran dan jenis font yang mudah dibaca. Untuk SC pendekatan yang digunakan adalah visual gambar/tulisan dan kinestetik halus/kasar. SC diberikan soal atau materi dengan warna, ukuran dan jenis font yang mudah dibaca dan diberikan instruksi dengan kegiatan yang membuatnya bergerak. Adapun pendekatan belajar yang digunakan untuk SD adalah dengan pendekatan visual menggunakan teknologi komputer. SD diberikan soal dan materi yang dapat dikerjakan dikomputer menggunakan animasi dan logika sesuai dengan kreativitasnya.

Ketiga, berdasarkan hasil evaluasi dari seluruh kegiatan pemetaan potensi seperti yang dijelaskan Royani dalam Liputan6.com (2014) maka ditemukan potensi-potensi anak dengan kesulitan belajar spesifik disleksia. Dapat disimpulkan bahwa CEG berpotensi dalam hal yang berhubungan dengan gambar. CEG dapat dengan jelas menggambarkan dan menceritakan urutan kejadian yang sistematis dengan gambar yang jelas. Kemudian, SC berpotensi dalam hal yang berhubungan dengan bangun ruang dan kinestetik kasar. SC dapat membuat kreasi dengan barang-barang yang ada disekitarnya menjadi mobilmobilan dan lapangan sepak bola. Dalam kegiatan fisik SC terlihat berpotensi dalam hal kinestetik kasar seperti bermain sepeda atau olahraga. Dan SD berpotensi dalam hal yang berhubungan dengan teknologi, logika berpikir dan kreasi bangun ruang. SD dapat membuat kreasi dengan barang-barang yang ada disekitarnya menjadi mobil-mobilan lengkap dengan sirkuitnya. Dalam kegiatan yang berkaitan dengan teknologi atau komputer yang membutuhkan logika, SD mampu mengerjakannya dengan benar. Melalui hasil dari proses pemetaan potensi ini maka dapat menjadi acuan guru dan orangtua dalam membantu, mengarahkan dan memfasilitasi anak dengan kesulitan belajar disleksia untuk menyadari dan memaksimalkan potensi yang ada dalam dirinya sebagai modal untuk kehidupannya saat ini dan dimasa yang akan datang. Setiap anak yang menyadai potensi dalam dirinya dapat meningkatkan motivasi dan kepercayaan dirinya dalam hal ini erat kaitannya dengan pandangan orang lain bahwa mereka di cap sebagai anak yang berbeda. 


\section{KESIMPULAN}

Pemahaman yang tepat terhadap keadaan peserta didik melalui identifikasi kebutuhan yang dilakukan guru adalah cara yang tepat untuk menentukan metode pembelajaran yang sesuai. Proses pembelajaran yang tepat dan sesuai bagi anak dengan kesulitan belajar spesifik dyslexia di Homeschooling Lentera Bangsa dapat membantu guru untuk memetakan potensi anak yang dapat dilihat melalui observasi kegiatan dikelas yang dilakukan secara berkelompok maupun individu.

Melalui proses pemetaan potensi anak dengan kesulitan belajar dyslexia pada level 3 yaitu CEG, SC, SD menghasilkan sebuah kesimpulan bahwa CEG berpotensi dalam hal yang berhubungan dengan gambar, SC berpotensi dalam hal yang berhubungan dengan bangun ruang dan kinestetik kasar, dan SD berpotensi dalam hal yang berhubungan dengan teknologi, logika berpikir dan kreasi bangun ruang. Potensi-potensi anak yang sudah ditemukan dapat membantu orangtua dalam mengarahkan dan memfasilitasi anak untuk dapat memaksimalkan potensinya tersebut sehingga menjadi modal bagi anak untuk menjalani kehidupan yang luar biasa.

\section{DAFTAR PUSTAKA}

Lyon, G. R. (1996). Learning disabilities. The future of children, 54-76.

Maslow, A. H. (1954). Personality and motivation. Harlow, England: Longman, 1, 987.

Solek P, Dewi K. 2015. Dyslexia Today Genius Tommorrow. Bandung : Dyslexia Association of Indonesia Production.

Sudjana, D. (2013). Pendidikan Luar Sekolah: Wawasan, Sejarah Perkembangan, Filsafat, Teori Pendukung, Asas. Bandung: Falah Production.

Suryani, Y. E. (2010). Kesulitan belajar. Magistra, 22(73), 33.

Widayanti, C. G., Rusmawati, D., \& Siswati, S. (2012). Profil Inteligensi Pada Siswa Dengan Kesulitan Belajar Di SD Negeri Gisikdrono Semarang. Jurnal Psikologi, 11(1), 10

Akses Internet

Febrida, M. 2014. Temukan Bakat Terpendam dengan Talents Mapping. [Online]. https://www.liputan6.com/health/read/2046524/temukan-bakat-terpendamdengan-talents-mapping, (diakses 30 Oktober 2018). 